\title{
Learning Objects and E-Learning: an Informing Science Perspective
}

\author{
Eli B. Cohen \\ Informing Science Institute, \\ Santa Rosa, CA, USA
}

EliCohen@InformingScience.org

\author{
Malgorzata Nycz \\ Wroclaw University of \\ Economics, Wroclaw, Poland
}

nycz@manager.ae.wroc.pl

\begin{abstract}
This papers provides an overview of e-learning from its fundamentals (what is knowledge, what is teaching) through how e-learning is being implemented using campus-wide Learning Content Management Systems (LCMS). While others, such as MacDonald et al. (2005), detail the transformation of education in light of changing technologies, this paper attempts from a variety of perspectives to make sense of the transformation. E-learning can be difficult to understand because different authors use the term differently. Still, beyond these apparent differences lies agreement on basics that this paper explores.

E-learning can best be understood in the broader context of using technology to meet society's needs for learning. It also requires us to understand that adult learners have psychological needs that e-learning must address. The Informing Science framework helps us understand that teaching in higher education involves a cast of roles that might best be performed by different specialists.

One of the most important aspects of e-learning are Learning Objects and the various software tools that aid in their development, storage, use in teaching, and administration. This is because elearning is often delivered using specialized software that assists teachers to create their courses, the student to use coursework, and the administrator to make previously developed coursework available for re-use. Learning Objects are the raw material of such systems.

E-learning can be delivered by a sole teacher or as part of a campus-wide effort. Campus-wide LCMSs make it possible for technologists, content specialists, instructional specialists, and students to work seamlessly to create and refine e-learning.
\end{abstract}

Keywords: Learning theory, learning objects, repositories, learning content management system

\section{E-Learning is for Adults}

E-learning is important for economic development, both of individuals and of society. Today's

Material published as part of this journal, either on-line or in print, is copyrighted by the Informing Science Institute. Permission to make digital or paper copy of part or all of these works for personal or classroom use is granted without fee provided that the copies are not made or distributed for profit or commercial advantage AND that copies 1) bear this notice in full and 2) give the full citation on the first page. It is permissible to abstract these works so long as credit is given. To copy in all other cases or to republish or to post on a server or to redistribute to lists requires specific permission and payment of a fee. Contact Publisher@InformingScience.org to request redistribution permission. economy relies on a labor force that not only possesses the necessary training, but that can continue to learn. That is, as jobs evolve in response to the changing economy, workers need to learn new skills, and this retooling occurs throughout their lives. In this way, e-learning is a technological response to society's need for lifelong, rapid learning. 
So what is e-learning? In one sense, it is the current technological solution to the problem of finding the best match between the needs of a given set of learners to learn a given content, using a given set of learning tools. In addition, Koohang \& Harman (2005, p. 77) define e-learning as "the delivery of education (all activities relevant to instructing, teaching, and learning) through various electronic media. The electronic medium could be the Internet, intranets, extranets, satellite TV, video/audio tape, and/or CD ROM." Technological improvements over time make this task a moving target as newer technology provides an ever increasing number of possibilities and options. In other words, e-learning takes into account four separate and related dimensions:

1. learning theories (specifically andragogy, as defined below),

2. psychological dimensions and demands of the learner,

3. technology, including all form of information and communication technologies (ICTs), and

4. content to be learned.

Below, we describe the first two of these and their interaction and mention some of the technological standards to support e-learning. This paper on e-learning limits it purview to web-based technologies and does not cover at all the content to be learned. Likewise, its focus is on the adult learner.

\section{Theory of Adult Learning: Andragogy}

Malcolm Knowles (1984) coined the term "andragogy" to describe and theorize how adults learn. The term is meant to contrast with the word "pedagogy," which denotes the teaching of children. Knowles' theory emphasizes that learning programs for adults must be responsive to the psychology of adults and how they learn. Compared with children, adults are self-directed and take responsibility for their own learning. Knowles' theory of andragogy instructs us that the best way to assist adults in their learning includes informing them why they need to know the topic, teaching the topic using experiential learning techniques, and having the adults solve a problem that is of immediate importance to them. For these reasons, the best strategies for teaching adults include role playing, simulation, case studies, and self-evaluation. The role of the instructor is that of resource rather than lecturer and grader.

\section{Problem-Based Learning}

The essence of teaching adults is to provide them with the tools they information and tools they need to solve problems and to provide these in the proper sequence, level of depth, and format to maximize their usefulness. Problem-based learning (PBL) aims to do just this. PBL is explored in greater depth in Gackowski (2003) and Bruce et al. (2004). Slack, Beer, Armitt, and Green (2003) describe issues in assessing PBL in general while Bahli and Büyükkurt (2004) explore issues in assessing PBL in group settings.

\section{Appreciating the Complexity of Teaching}

The Informing Science framework (ISF), as seen in Cohen $(1999,2003,2004)$ informs our understanding of learning in general and e-learning in particular. We describe the framework below, but it is worthwhile to state here some of its implications to the topic at hand.

When applied to higher education, ISF helps us understand that all learners have their own psychological makeup and their own pre-existing knowledge, skills, and abilities. Learning occurs when the adult learner's immediate requirement to solve some task or tasks is paired with a series of learning opportunities. ISF suggests that teaching occurs by the instructor creating, sequencing, and delivering learning opportunities. Put another way, the roles of the instructor include creating 
a knowledge delivery environment, regardless of whether the instructor also creates new knowledge.

Finally, ISF informs us that knowledge delivery is more than just presenting knowledge. The typical college student is literate, so text books can be very effective as tools for the presentation of knowledge. And teaching is more than just giving a textbook to a student. Ideally, the knowledge, skills, and abilities that are being learned must be packaged, sequenced, and delivered in response to each learner's unique needs. The instructor is the one responsible for this packaging of learning resources and opportunities.

(When we conceive of adult learning in this way, that anyone can learn in typical university settings is a bit of a miracle. "Good students" is the term we use for those whose intelligence allows them to learn despite poorly constructed teaching systems.)

\section{What is Knowledge?}

E-learning systems are said to convey knowledge, but this begs the question, "What is knowledge?" This paper acknowledges that knowledge is often difficult to define fully, measure accurately, and apply uniformly. Here is a brief overview of the issues.

Some authors, such as Olenski (1997), define knowledge just as a collection or accumulation of information. Most, however, view knowledge as being more than information; that information needs to be coupled with the ability to use it. Baborski (1994) defines knowledge as a set of information that enables one to draw conclusions from premises. Here again, we understand knowledge is not just information, but has an accompanying ability to apply this information to some problem or task. This is a key point. Under these definitions, knowledge exists only as an artifact of a problem or task in interaction with the problem solver.

Conveying knowledge is a task of transmitting to the learner an understanding of the problem or task in a form that makes sense for that learner. This point is made even clearer when we define knowledge in terms of psychology.

\section{Knowledge as a Psychological State}

The most succinct definition of knowledge can be found on WordNet (n.d.) as "the psychological result of perception and learning and reasoning."

In other words, to understand what knowledge is, we need to understand psychological aspects of the individual learner. E-learning certainly involves conveying knowledge. And since the definition of knowledge is linked to understanding the problem or task faced by the learner, we need to consider the learners' psychology as well. Therefore, to understand e-learning, we need to understand the psychological needs of the learner. Stated in different words, the best ways to teach require involving the student in the problem to be solved. For this reason, the role of the teacher under e-learning is evolving.

\section{The Role of the "Teacher" is Evolving}

As we noted above, the role of the teacher in e-learning is not limited to being the presenter of knowledge. E-learning requires more from teachers than, say, merely presenting lectures. ICT enables teachers to package learning opportunities in an increasing number of alternative ways so as best to meet the varying needs of different students (and college deans).

This is not new. One of the first ICTs to change the role of the teacher may well have been the postal service in its role as part of the delivery system for instruction material to distant learners. Even today, some schools, such as the University of South Africa, rely principally on mail for the 
delivery of its correspondence courses. But more and more, mail is being replaced by email, and printed handouts are being replaced with web-based knowledge transmission.

New ICTs offer new opportunities for teaching. They build on the same principles and opportunities of teaching to many individuals at each learner's own rate (compared with teaching to a class of students meeting at the same time in the same place). Indeed, even traditional classroom teaching is being supplemented by the lessons learned on how best to teach at a distance.

In the traditional lecture-based education typically found in large universities, students and teachers are at the same place (often a classroom) at the same time, learning the same lesson. The traditional approach holds that teachers (and perhaps the textbook) are the principal source of knowledge delivered to students. Teachers can call upon ICT support, such as audio/ video materials, slides or films. Students can use supplementary means to obtain knowledge, such as manuals, books, and such. But the lecture is the key to learning.

(The rationale behind lecture-based education is that it is cost-effective, not that it is efficacious in conveying knowledge.)

Instruction in the distance learning system needs to be different, if for no other reason than the teacher is not physically present to keep students awake. E-learning systems replace the teacher as the center for learning. In e-learning systems, the principle source of knowledge is not a teacher but knowledge-bases collected, assembled, and sequenced by the teacher, along with possibly with links to other sources of information, typically accessible via the Internet. The teacher role shifts from lecturer to that of course developer and, once a course is in session, the course facilitator. The main differences between models of education are shown in Table 1 .

Table 1: Types of education models

\begin{tabular}{|c|c|c|}
\hline MODEL & $\begin{array}{c}\text { Traditional model } \\
\text { of education }\end{array}$ & $\begin{array}{c}\text { Distance education } \\
\text { system (e-learning) }\end{array}$ \\
\hline Main knowledge source & teacher & $\begin{array}{c}\text { knowledge bases in education } \\
\text { system; any knowledge source } \\
\text { accessed via the Internet }\end{array}$ \\
\hline $\begin{array}{c}\text { Additional knowledge } \\
\text { sources }\end{array}$ & $\begin{array}{c}\text { books, manuals, audio, } \\
\text { and video materials }\end{array}$ & $\begin{array}{c}\text { traditional sources } \\
\text { teacher, fellow students }\end{array}$ \\
\hline Assessment & only by teacher & $\begin{array}{c}\text { system and teacher who is } \\
\text { responsible for final assessment }\end{array}$ \\
\hline Quality of education & $\begin{array}{c}\text { depends on teacher's quality, } \\
\text { level of knowledge, and ability to } \\
\text { share knowledge }\end{array}$ & $\begin{array}{c}\text { depends on quality of electronic } \\
\text { knowledge sources and other } \\
\text { didactic materials }\end{array}$ \\
\hline
\end{tabular}

The students' role in e-learning can and should become one of problem solvers. When used properly, e-learning systems enable students to be active in their own knowledge acquisition, often using the following forms of cooperative learning:

- common learning within the team, (students no longer need to find a time to meet, as many meetings can be held asynchronously)

- interactive process of group building of knowledge, (students leave notes for other students to read and critique) 
- active participation in generating and selecting of information, (not every student needs to be an expert in all topics; instead, they can teach one another the topics that interest them the most)

- constructing knowledge in the context of other students' points of view. (student interaction teaches them that more than one viewpoint can be valid)

\section{Where and When Does Teaching Take Place?}

No longer is teaching limited to taking place with all the students at the same place at the same time. E-learning can be seen in terms of four basic situations, as seen in Table 2:

1. The same time and the same place of education - students and teacher are synchronized (in time and place). This kind of a model can be seen as a traditional model.

2. The same time, different places - teaching occurs at the same time, but uses media transmission technologies so that students can be located in different places (a synchronous model).

(This is often seen in "TV" classrooms in which while the teacher talks to one class of students, the lecture is telecast to other classrooms. Internet-based online meetings or chat sessions are other examples of this.)

3. Different times, the same place - when students are taught in educational center and they can come there when they want to learn and have access via computer net, mainly Internet to the education system,

4. Different times, different places - (an asynchronous model) when students access education system from different places at time convenient to them. All communication is realized through ICT, typically the Internet.

Table 2: Four basic situations for Teaching/Learning

\begin{tabular}{|l|l|l|}
\hline & $\begin{array}{l}\text { Same Time } \\
\text { (Synchronous) }\end{array}$ & Asynchronous \\
\hline Same Place & $\begin{array}{l}\text { Type 1: traditional } \\
\text { Classroom }\end{array}$ & Type 3: Learning Lab \\
\hline $\begin{array}{l}\text { Different Learning } \\
\text { Locations }\end{array}$ & $\begin{array}{l}\text { Type 2: "TV” } \\
\text { classrooms }\end{array}$ & Type 4: distance education \\
\hline
\end{tabular}

\section{Characteristics of an E-Learning Environment}

\section{Components of an E-Learning System}

The Informing Science Framework (ISF) (Cohen, 1999, 2003) is useful for understanding elearning systems. Above we introduced some of the implications of ISF. Let us now examine this framework in greater detail as applied to teaching in Higher Education and depicted in Figure 1. ISF holds that many phenomena involving using ICT to inform clients, including learning in higher education, can be understood through the relationship of three environments: the information development meta-environment, the delivery environment, and the information using environment.

In brief, the information development meta-environment deals with the making of plans for informing clients. This meta-environment includes a model for creating plans, plans for creating 
instances, and instances. This corresponds in the higher education to activities that range from (at a university level) deciding on what faculties or majors to offer, to developing curricula for a given major, to developing and implementing individual courses. The delivery environment is concerned with the available ICT as well as the packaging of the information into the optimal sequence and media for the target learner. The information using environment contains the experts on the topics being taught and the students who wish to learn this information.

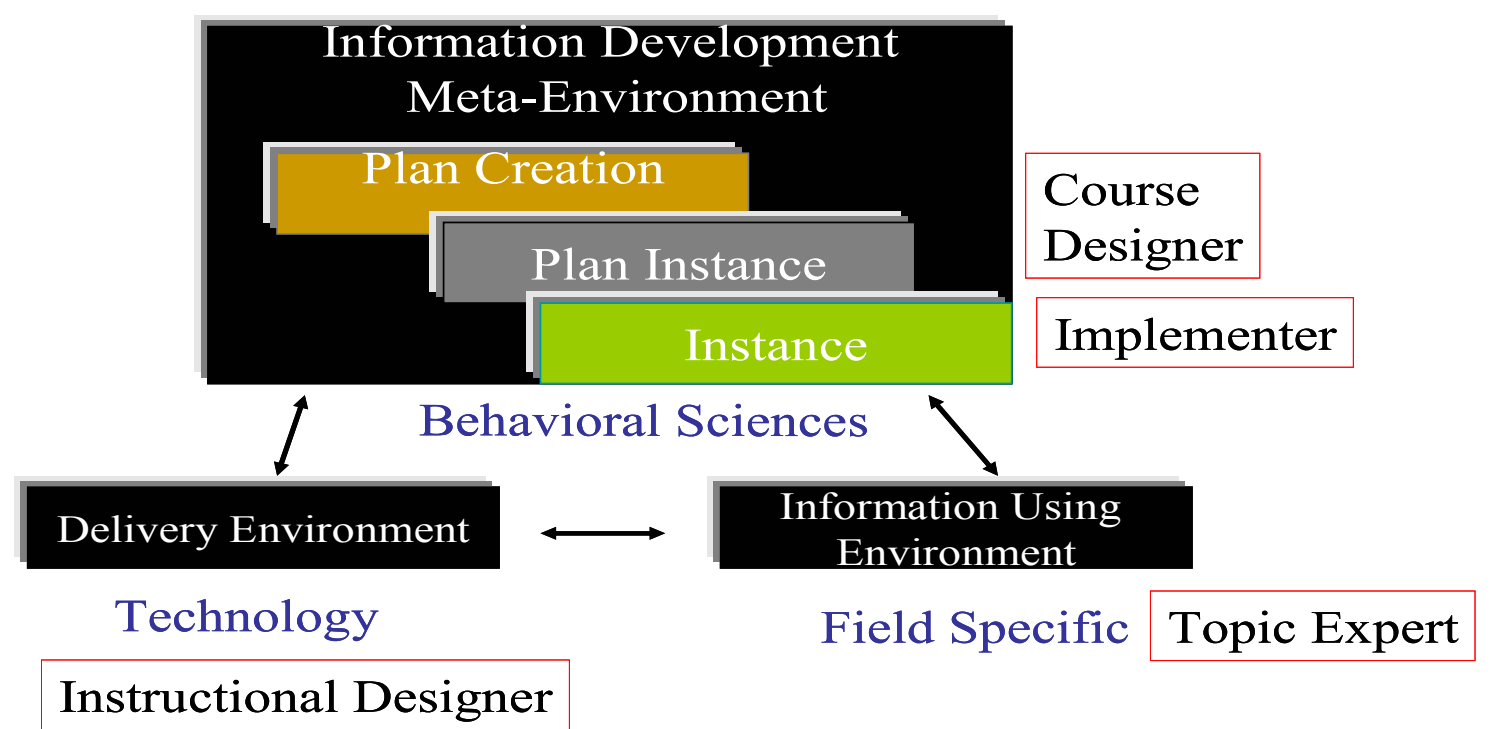

Figure 1: The Informing Science Framework Applied to Higher Education

One implication of the ISF that we have not yet explored is that it helps us understand and tease out the various roles required in teaching. As applied to higher education, the three environments correspond to the roles of course designer, instructional designer, topic expert, and course implementer, as noted in Figure 1. In many college classrooms, the same person plays these various roles, such as determining the course goals and objectives, gathering course materials and creating new course material, selecting and sequencing the presentation of these materials, and then presenting the course to one or more sets of students, assessing student learning and making slight adaptations to the course presentation to meet student (and administrative) needs. But these roles are distinct. By recognizing that these roles are distinct, we understand that different people may specialize in one or another role. This understanding allows us to broaden our thinking about education and how it can be conducted in e-learning.

Of particular interest to readers, the Informing Science Framework helps us appreciate the role of the instructional designer. The person(s) who play this role needs to understand both the technology and how it can best be used to support e-learning. The instructional designer needs to scout out and evaluate ICT developments for possible use in e-learning. Wiley and Waters (2005) describe the role of the Instructional Designer.

\section{Learning Objects and their Roles in E-Learning}

Understanding the various roles involved in teaching and the possibility of task-specialization leads to a fuller understanding of the impact of learning objects on the future of higher education. The course designer may assemble a course from, for example, pre-existing learning objects that have been created by others. 
The topic expert creates knowledge that is "packaged" for others to re-use by instructional designers. The course designer's job is to fashion and weave these pre-packaged learning segments into the design for a course. The course is actually conducted by the course implementer who assists the students to interact with the course material. The formal term for the "packaged" knowledge is a learning object.

A learning object is a type of knowledge object. Objects, by definition, are self-contained and reusable. To be re-usable, its content and presentation are separated. Learning objects are types of knowledge objects in the sense that their goal is to provide knowledge in support of an associated learning objective.

Commonly, learning objects' presentations include a variety of media, that is, they are multimedia in format, but this is not a requirement. Likewise, commonly their content is organized around standards such as Sharable Content Object Reference Model (SCORM http://www.adlnet.org) or IEEE Learning Object Metadata (IEEE LOM - http://ltsc.ieee.org) to create metadata about the contents of the learning object resource. SCORM and IEEE LOM are standards that aid reusability, interoperability, and accessibility of learning objects. Malaxa and Douglas (2005) deal with the issue of creating metadata for learning objects in greater depth. Friesen (2005) discusses in greater depth e-learning standardization in the quest toward interoperability.

Learning objects are not necessarily strange, novel, and futuristic entities. In the minimum, learning objects can be created by capturing (to video) and indexing individual lectures with associated presentation materials, as seen in Bodendorf, Schertler, and Cohen (2005). This collection, storage, and reuse enable the lecturer to turn the event of giving a lecture into more than a single performance to a single set of students.

\section{Authoring Resources}

Bodendorf, Schertler, and Cohen's (2005) article makes clear the need to provide tools to the people creating learning objects. The tool described there allows mere professors, with no extraordinary training, to create rudimentary learning objects. Recker et al. (2005) describe a variety of tools available to both professors and instructional designers for creating learning objects. These tools are known as authoring resources.

\section{Learning Object Repositories}

Associating and storing metadata about the learning object with the learning object makes it possible for a course designer to search for and locate existing learning objects. For this to work, those objects must be stored in an accessible location and form. Such locations are called Learning Object Repositories. There are two types of learning object repositories. The first type contains only the metadata for learning objects such as MERLOT (http://www.merlot.org). The actual learning objects are stored in various locations. The second type holds both the metadata and the learning objects in one location. An example of this type of repository is DSpace open software (dspace.org). Nash (2005) provides a list of learning object repositories. Namath, Fritz, King, and Boren (2005) point out that the term Learning Object Repository is used to mean two related, but different things: a repository for local (university) needs, and a general clearinghouse for learning objects from across many different sources. The term, as presently used in the literature, is applied to both of these situations.

\section{Learning Content Management System}

Not surprisingly, systems are available to combine authoring resources with tools for storing and retrieving learning objects. The term Learning Content Management System (LCMS) is used for 
a system that is more capable than a simple Learning Object Repository. Commonly, this term is used for systems that contain components that support authoring, combined with a learning object repository and tools for delivering the objects to students, as well as administrative tools. KaplanLeiserson (n.d.) defines it as a "software application (or set of applications) that manages the creation, storage, use, and reuse of learning content" Hayhoe (1998) depicts these same components using slightly different wording, as seen in Figure 2:

1. System for Collecting and Creating Knowledge Assets (Content authoring system),

2. Resource Management (a Learning Object Repository),

3. System for delivering content to Students (Content delivery system), and

4. Systems Maintenance (Administrative tools).

An example of an Open Source LCMS is the Basic e-learning Tool Set (BELTS) Project (http://belts.sourceforge.net) while Blackboard Academic Suite (http://blackboard.com) is an example of a commercial LCMS. Moodle (http://moodle.org) also deserves mention here, even though it is not a full LCMS. It is open source software that provides a web-based content delivery system and administrative tools, as well as authoring tools, that lacks a Learning Object Repository.

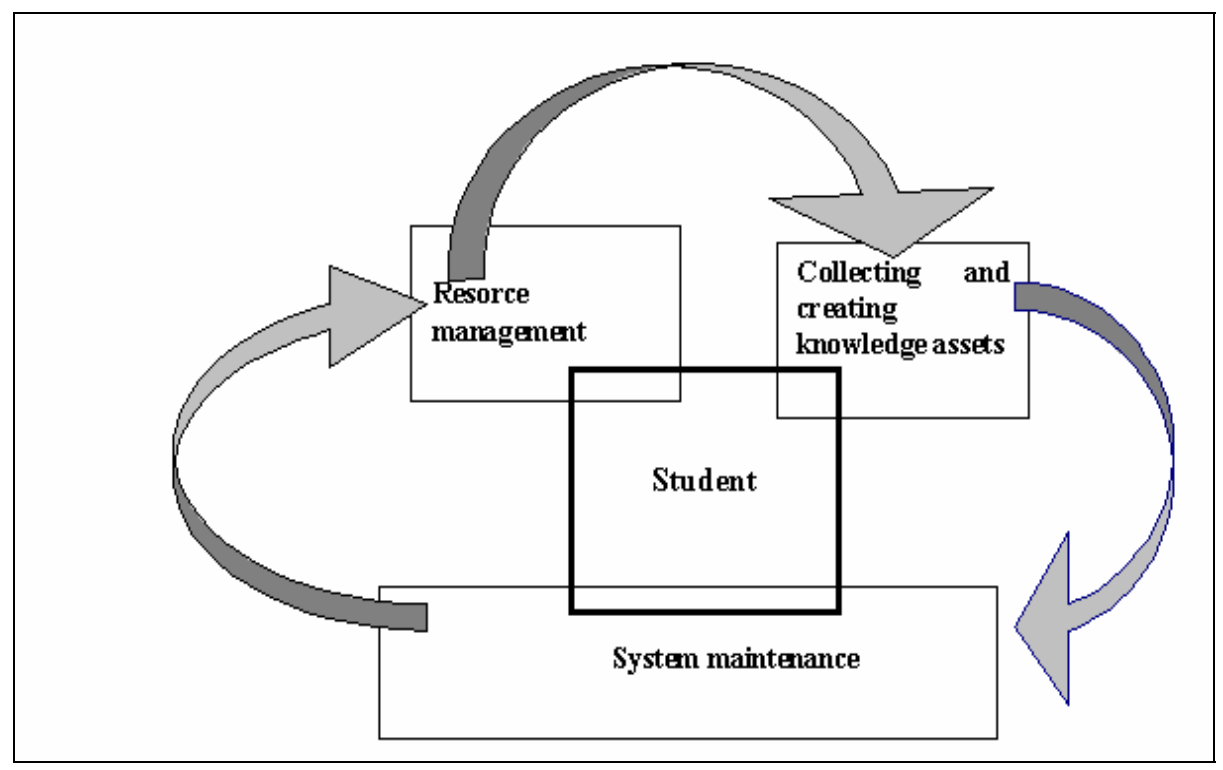

Figure 2: Learning Content Management System, (Adapted from Hayhoe, 1998)

Up to this point, we have looked at LCMS from the point of view of the objects. Hayhoe (1998) shows in our Figure 3 how a center for e-learning might function with respect to the system mentioned above. Commonly, campuses standardize on one LCMS and set up a Center for e-learning to support the venture. Let us now focus on how LearningSpace, one such LCMS, works. 


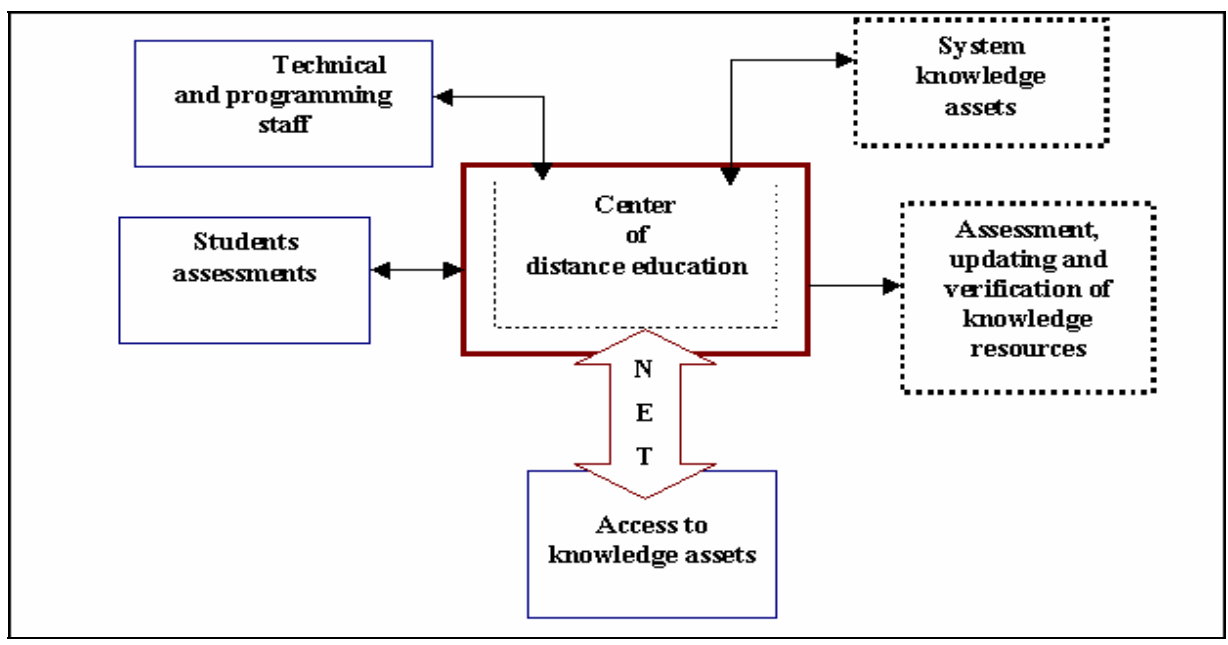

Figure 3: Schematic organization for a center for e-learning, Source: (Hayhoe, 1998)

\section{LearningSpace as a LCMS}

To understand the relationship between Centers for e-learning and the LCMS, it is worthwhile to explore one LCMS in detail; IBM Lotus Corporation's product LearningSpace is a commercial LCMS. It is a Domino application; this means that the system runs on top of (and so requires) other proprietary software on a central server. As with other LCMSs, students interact with the instructor and other students through computer network asynchronously. Students work at their own pace, so long as assignments are completed and the exams taken by their due dates.

LearningSpace offers a multi-database application suite that supports a rich spectrum of content delivery. Specifically, it relies upon the following five databases:

1. A Schedule database, which is a central module for participants to navigate through course materials. The schedule may be developed and organized by time frames as well as by models for self-paced instruction. The schedule links participants to readings, assignments, and quizzes.

2. A Media Center database, which contains a variety of multimedia documents: articles, videos, sound recordings, newsletters, chapters, abstracts, and summaries. It also can provide access to external sources, such as the web and other content repositories.

3. A virtual Course Room, which acts as an interactive, facilitated environment for participants to engage in public and private discussions among themselves and with the instructor, to share information, and to complete team tasks and assignments.

4. A profiles database, which is a collection of participant descriptions including contact information, photographs, experience and interests.

5. An Assessment Manager database that is accessible only by the instructors and that serves as an evaluation tool for the instructor. The system stores test results and other feedback on each student in this database. Quizzes are posted in the schedule database and are then transferred to this database.

\section{LearningSpace Participants and Their Roles in the Informing Science Framework}

LearningSpace participants include administrators, designers, instructors, students and users.

Here is what we mean by these terms and how they relate to the Informing Science Framework: 
- Administrator. The administrator makes sure that course has all the proper students and databases, as well as conducting many others tasks needed to keep the system working. For example, the administrator backs up the databases, adds and removes course participants and specifies software settings for a course. There is no comparable role in the Informing Science framework.

- Designer. The designer role is quite similar to the Course Designer in the Informing Science Framework shown in Figure 1. This participant is responsible for assembling the contents of the developed courses. In addition, the LearningSpace-specific tasks include setting software parameters of the course, registration of students, identification of instructors or facilitators, completion of the Course Profile procedure in LearningSpace Central, identification and then purchase or development of any necessary course materials.

- Instructor. The instructor is directly comparable to the Course Implementer in the Informing Science framework. The instructor interacts with students using one of the developed courses.

- Student and User. The student role corresponds to the client in the Informing Science framework. LearningSpace enrolls users, people with a Lotus Notes account, in one or more courses, making them students.

\section{Conclusion}

This paper has developed the idea of e-learning from its fundamental (what is knowledge, what is teaching) through how e-learning is being implemented using campus-wide LCMSs. We have seen that e-learning can be difficult to understand because many people use the term differently. Beyond the differences are some basics agreements that this paper explored. E-learning needs to be understood in the broader context of using technology to meet society's needs for learning. It also requires us to understand that adult learners have psychological needs that e-learning must address. The Informing Science framework helps us understand that teaching in higher education involves a cast of roles that might best be performed by different specialists.

E-learning is often delivered using specialized software that assists teachers create their courses, the student in using coursework, and the administrator in making previously developed coursework available for re-use. It works hand-in-hand with learning objects and learning object repositories.

Campus-wide LCMSs make it possible for technologists, content specialists, instructional specialists, and students to work seamlessly to create and refine e-learning.

\section{References}

Bahli. B., \& Büyükkurt, M. D. (2004). Group performance in information systems project groups: An empirical study. Journal of Information Technology Education, 4, 97-113. Available at http://jite.org/documents/Vol4/v4p097-113Bahli22.pdf

Bodendorf, F., Schertler, M., \& Cohen, E. (2005). Producing reusable web-based multimedia presentations. Interdisciplinary Journal of Knowledge and Learning Objects, 1, 127-142. Available at http://ijklo.org/Volume1/v1p127-142Bodendorf.pdf

Bruce, C., Buckingham, L., Hynd, J., McMahon, C., Roggenkamp, M., \& Stoodley, I. (2004). Ways of experiencing the act of learning to program: A phenomenographic study of introductory programming students at university. Journal of Information Technology Education, 3, 143-160. Available at http://jite.org/documents/Vol3/v3p143-160-121.pdf 
Cohen, E. B. (1999). From ugly duckling to swan: Reconceptualizing information systems as a field of the discipline informing science. Journal of Computing and Information Technology, 7(3), 213-219.

Cohen, E. B. (2003). (2003). A modest proposal for the survival of our profession: Applying the informing science framework to higher education [Keynote Address]. Proceedings of the Australasian Society for Computers in Learning in Tertiary Education (ASCILITE), Adelaide, Australia, December 2003.

Cohen, E. B. (2004). Applying the informing science framework to higher education: Knowledge development, management, and dissemination. Konferencja Pozyskiwanie wiedzy i zarządzanie wiedzą (Proceedings of the Knowledge Acquisition and Management Conference) May 13-15, 2004 Kule, Poland.

Friesen, N. (2005). Interoperability and learning objects: An overview of e-learning standardization. Interdisciplinary Journal of Knowledge and Learning Objects, 1, 23-31. Available at http://ijklo.org/Volume1/v1p023-031Friesen.pdf

Gackowski, Z. J. (2003). Case/real-life problem-based learning with information system projects. Journal of Information Technology Education, 2, 357-365. Available at http://jite.org/documents/Vol2/v2p357$\underline{365-128 . p d f}$

Hayhoe, G. F. (1998). Evaluating distance learning in graduate programs: Ensuring rigorous, rewarding professional education. Paper presented at the International Professional Communication Conference 98 on 23 September 1998 in Québec City, PQ, Canada. Retrieved Dec. 24, 2005 from http://www.puw.pl/downloads/docs/evaluating.pdf

Kaplan-Leiserson, E. (n.d.). Learning circuits glossary. American Society for Training \& Development Retrieved from http://www.learningcircuits.org/glossary

Knowles, M. (1984). Andragogy in action. San Francisco: Jossey-Bass.

Koohang, A. \& Harman, K. (2005). Open source: A metaphor for e-learning. Informing Science: The International Journal of an Emerging Transdiscipline, 8, 75-86. Available at http://inform.nu/Articles/Vol8/v8p075-086Kooh.pdf

MacDonald, C. J., Stodel, E., Thompson, T. L., Muirhead, B., Hinton, C., Carson, B., \& Banit, E. (2005). Addressing the e-learning contradiction: A collaborative approach for developing a conceptual framework learning object. Interdisciplinary Journal of Knowledge and Learning Objects, 1, 79-98. Available at http://ijklo.org/Volume1/v1p079-098McDonald.pdf

Malaxa, V. \& Douglas, I.. (2005). A framework for metadata creation tools. Interdisciplinary Journal of Knowledge and Learning Objects, 1, 151-162. Available at http://ijklo.org/Volume1/v1p151162Malaxa28.pdf

Namuth, D., Fritz, S., King, J. Boren, A. (2005). Principles of sustainable learning object libraries. Interdisciplinary Journal of Knowledge and Learning Objects, 1, 181-196. Available at http://ijklo.org/Volume1/v1p181-196Namuth.pdf

Nash, S. S. (2005). Learning objects, learning object repositories, and learning theory: Preliminary best practices for online courses. Interdisciplinary Journal of Knowledge and Learning Objects, 1, 217-228. Available at http://ijklo.org/Volume1/v1p217-228Nash.pdf

Nycz, M. \& Owoc, M. (Eds.). (2004). Pozyskiwanie wiedzy i zarzadzanie wiedza. [Knowledge acquisition and management]. Prace Naukowe nr 1011, Wroclaw Economics Academy Publishing House, Wroclaw, Poland.

Nycz, M. \& Smok, B. (2003). Distance education as a way to meet the challenges of the XXI Century. Proceedings of the SympoTIC'03 Joint $1^{\text {st }}$ Workshop on Mobile Future \& Symposium on Trends in Communications (pp. 26-28), IEEE CS Section, Bratislava, Slovakia, October 2003.

Olenski, J. (1997). Standardy informacyjne w gospodarce. [Information standards in the economy.] Warsaw University Publishing House, Warsaw [in Polish].

Recker, M., Dorward, J., Dawson, D., Mao, X., Liu, Y., Palmer, B., Halioris, S., \& Park, J. (2005). Teaching, designing, and sharing: A context for learning objects. Interdisciplinary Journal of Knowledge and Learning Objects, 1, 197-216. Available at http://ijklo.org/Volume1/v1p197-216Recker.pdf 
Slack, F., Beer, M., Armitt, G. \& Green, S. (2003). Assessment and learning outcomes: The evaluation of deep learning in an on-line course. Journal of Information Technology Education, 2, 305-317. Available at http://jite.org/documents/Vol2/v2p305-317-29.pdf

Wiley, D. A. \& Waters, S. H. (2005) Scoping and sequencing educational resources and speech acts: A unified design framework for learning objects and educational discourse. Interdisciplinary Journal of Knowledge and Learning Objects, 1, 143-150. Available at http://ijklo.org/Volume1/v1p143150Wiley.pdf

WordNet. (n.d.) Cognitive Science Laboratory Princeton University. Retrieved November 15, 2005 from http://wordnet.princeton.edu/perl/webwn?s=knowledge

\section{Biographies}

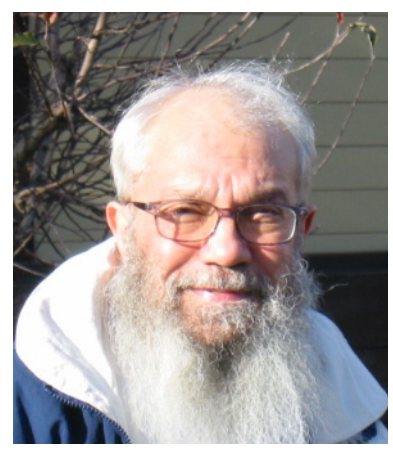

Eli Cohen directs the Informing Science Institute and is Editor-inChief of Informing Science: the International Journal of an Emerging Transdiscipline. He is professor of information systems at the Kozminski School of Entrepreneurship and Management in Warsaw, Poland.

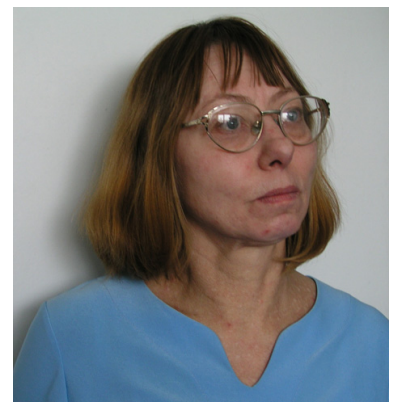

Malgorzata Nycz, Ph.D. Eng., is a lecturer in the Faculty of Management and Computer Science, Wroclaw University of Economics, Poland. Dr. Nycz has authored over 50 publications mostly oriented on intelligent systems topics, data warehousing and distance learning issues. Her current research is in the area of intelligent systems with focus on data analysis, information and knowledge discovery from databases, and modern education including e-learning processes. 